no.

GL-92-19

UG-92/07

t 1992

LIBRARY ?-19

FACILITIES ENGINEERING

USE ONLY

\title{
USER'S GUIDE: CRACKING AND SEATING OF PORTLAND CEMENT CONCRETE PAVEMENTS
}

US-CE-C PROOERTY OF THE UNITED STATES GOVERNMENT

by

Randy C. Ahlrich

US Army Engineer Waterways Experiment Station Vicksburg, MS 39180-6199

Approved For Public Release; Distribution Is Unlimited

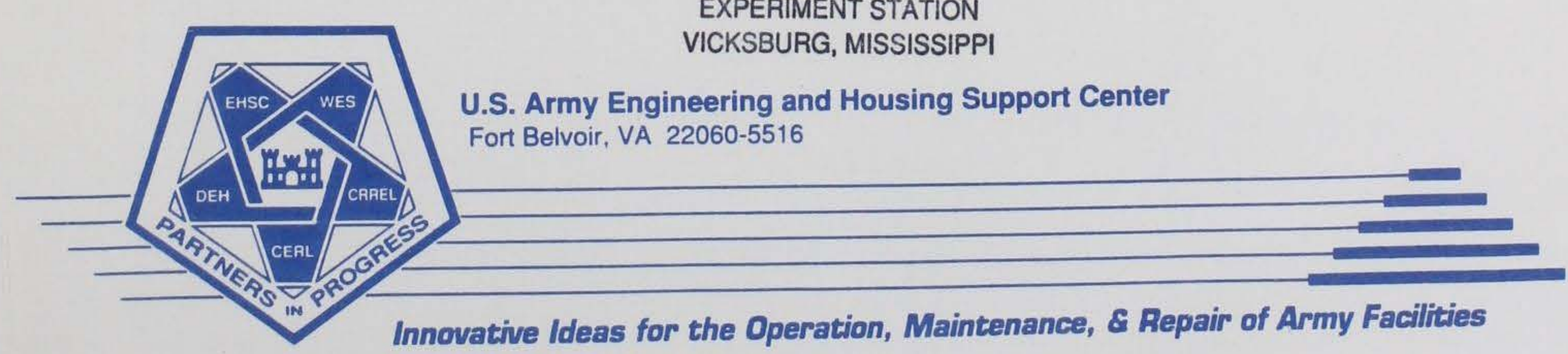


Public reporting burden for this collection of information is estimated to average 1 hour per response. inciuding the time for reviewing instructions, searching existing data sources. gathering and maintaining the data needed. and completing and reviewing the collection of information. Send comments regarding this burden estimate or any other aspect of this Devis Highway, Suite 1204, Arlington, VA 22202-4302, and to the Office of Management and Budget, Paperwork Reduction Project (0704-0188), Washington. DC 20503.

\begin{tabular}{|l|l|l|}
\hline 1. AGENCY USE ONLY (Leave blank) & $\begin{array}{c}\text { 2. REPORT DATE } \\
\text { August } 1992\end{array}$ & $\begin{array}{c}\text { 3. REPORT TYPE AND DATES COVERED } \\
\text { Final report }\end{array}$ \\
\hline
\end{tabular}

\section{TITLE AND SUBTITLE \\ User's Guide: Cracking and Seating of Portland Cement Concrete Pavements} 5. FUNDING NUMBERS

\section{AUTHOR(S)}

Randy C. Ahlrich

\section{PERFORMING ORGANIZATION NAME(S) AND ADDRESS(ES)}

USAE Waterways Experiment Station

Geotechnical Laboratory

3909 Halls Ferry Road

Vicksburg, MS 39180-6199

9. SPONSORING / MONITORING AGENCY NAME(S) AND ADDRESS(ES)

US Army Corps of Engineers

Engineering and Housing Support Center

PERFORMING ORGANIZATION REPORT NUMBER

Bldg. 2593

Fort Belvoir, VA 22060-5516

11. SUPPLEMENTARY NOTES

12a. DISTRIBUTION/AVAILABILITY STATEMENT

12b. DISTRIBUTION CODE

Approved for public release; distribution is unlimited.

\section{ABSTRACT (Maximum 200 words)}

Asphalt concrete overlays of a jointed or cracked portland cement concrete (PCC) pavement can develop reflective cracking because of either horizontal or vertical movement of the PCC. One method that can be used to reduce reflective cracking is to crack and seat the PCC prior to placement of the asphalt concrete overlay.

The description, applicability, benefits, limitations, costs, recommended uses, and location of demonstration sites for cracking and seating technology are discussed.

\begin{tabular}{|c|c|c|c|}
\hline \multirow{2}{*}{\multicolumn{3}{|c|}{$\begin{array}{l}\text { 14. SUBJECT TERMS } \\
\qquad \begin{array}{ll}\text { Asphalt concrete } \\
\text { Concrete }\end{array} \\
\text { Cracking }\end{array}$}} & \multirow{2}{*}{ 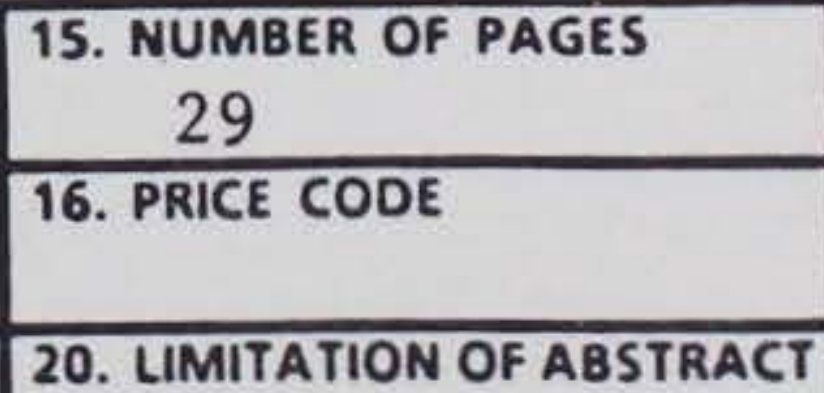 } \\
\hline & & & \\
\hline $\begin{array}{l}\text { 17. SECURITY CLASSIFICATION } \\
\text { OF REPORT } \\
\text { Unclassified }\end{array}$ & $\begin{array}{l}\text { 18. SECURITY CLASSIFICATION } \\
\text { OF THIS PAGE } \\
\text { Unclassified }\end{array}$ & $\begin{array}{l}\text { 19. SECURITY CLASSIFICATION } \\
\text { OF ABSTRACT } \\
\text { Unclassified }\end{array}$ & \\
\hline
\end{tabular}




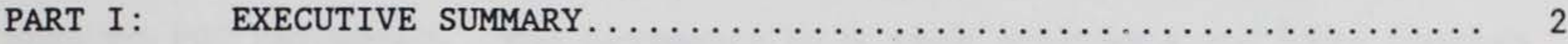

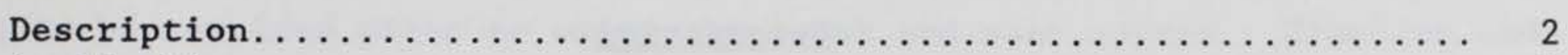

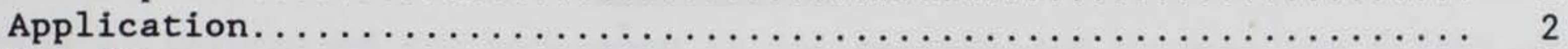

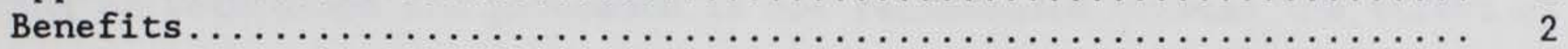

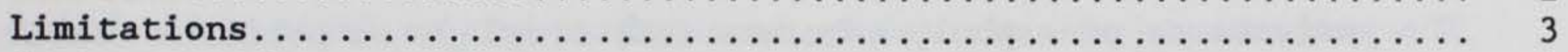

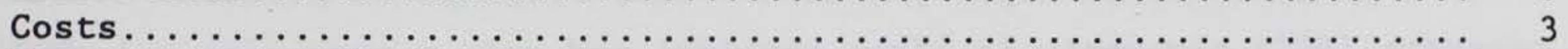

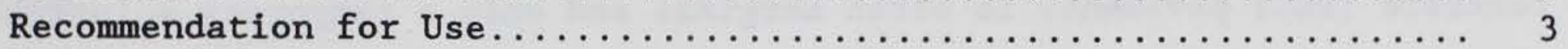

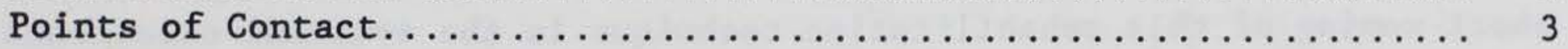

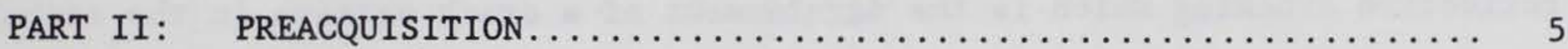

Description of Cracking and Seating..................

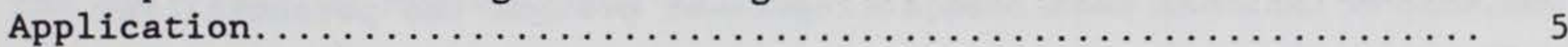

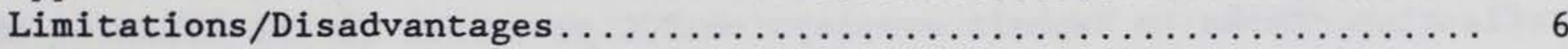

FEAP Demonstration/Implementation Sites . . . . . . . . . . . .

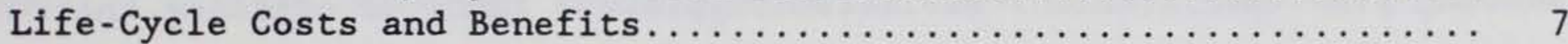

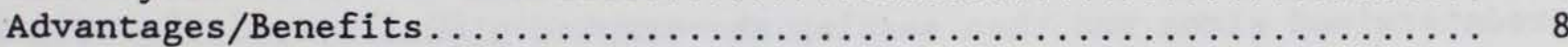

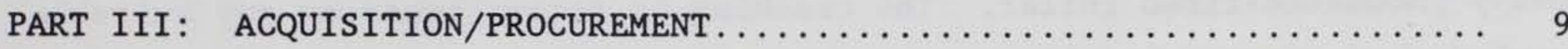

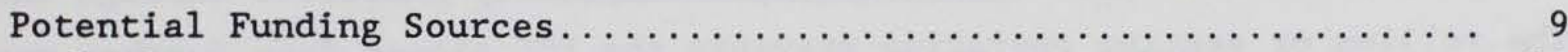

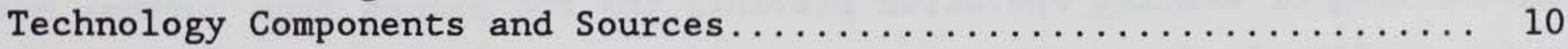

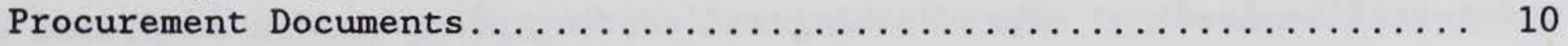

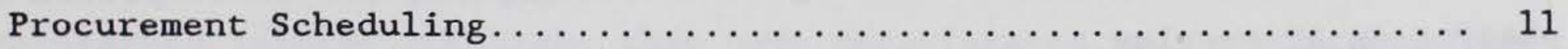

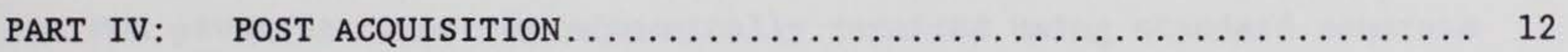

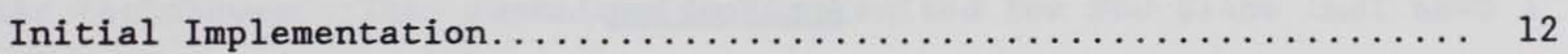

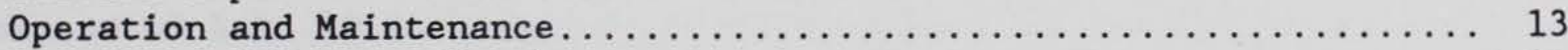

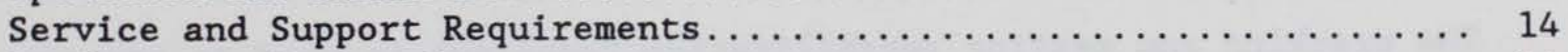

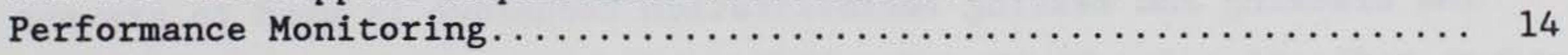

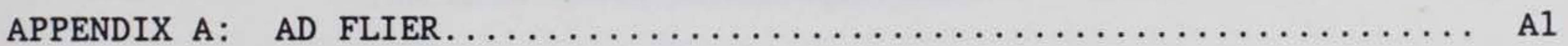

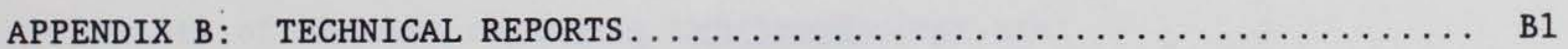

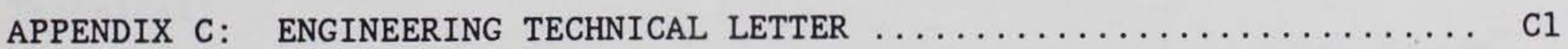


USER'S GUIDE: CRACKING AND SEATING OF PORTLAND CEMENT CONCRETE PAVEMENTS

\section{PART I: EXECUTIVE SUMMARY}

\section{Description}

The performance of asphalt concrete (AC) overlays on portland cement concrete (PCC) pavements is often marginal and only a temporary solution. A short-coming of this rehabilitation technique is the eventual occurrence of reflective cracking which is the development of a crack pattern in the asphalt overlay similar to the crack and joint pattern in the underlying PCC pavement. One method that has been used to reduce or prevent the potential for reflective cracks in asphalt overlays on PCC pavements is the cracking and seating procedure. This rehabilitation process involves cracking the PCC into predetermined sizes and then seating the cracked pieces by rolling with a heavy pneumatic-tired roller. The cracking is accomplished by any suitable method that creates hairline cracks that completely penetrate through the PCC. The rolling or seating operation prevents the PCC pieces from further movement under traffic loading. The cracking and seating procedure is completed by placing an AC overlay.

\section{Application}

The cracking and seating rehabilitation technique is used to prevent and reduce reflective cracks when overlaying PCC slabs with AC.

\section{Benefits}

The cracking and seating procedure can save construction costs when compared to repairing and removing the existing PCC slabs. This rehabilitation technique extends the service life of the existing pavement and reduces future maintenance costs. The crack and seat procedure can decrease the disruption of traffic and allow the pavement to stay open to traffic during construction. The new asphalt overlay improves the ride and surface smoothness and restores the skid resistance. 


\section{Limitations}

This rehabilitation technique cannot be used to rehabilitate structurally unsound PCC pavements. PCC pavements with weak subgrades and base courses have to be repaired prior to using the crack and seat method. Cracking and seating of reinforced PCC pavements is not recommended because the effect of the reinforcing steel on the performance of asphalt overlays is not well defined.

\section{$\underline{\text { Costs }}$}

The unit cost of cracking and seating is approximately 30 to 50 percent lower than PCC repair or removal, and reconstruction of a new flexible pavement. Typical costs for cracking and seating the existing PCC pavement range from $\$ 0.25$ to $\$ 1.00$ per square yard.

\section{Recommendation for Use}

The cracking and seating rehabilitation technique is recommended for nonreinforced jointed PCC slabs that have deteriorated to a condition where the PCC pavement cannot be economically repaired using standard concrete repair techniques. This technique is best suited for PCC slabs that have a thickness of 6 to 10 inches.

\section{Points of Contact}

Points of contact regarding this technology are:

Technical:

Director

US Army Engineer Waterways Experiment Station

ATTN: CEWES-GP-Q (Mr. Randy C. Ahlrich)

3909 Halls Ferry Road

Vicksburg, MS 39180-6199

Telephone: 601-634-3367

Facsimile: 601-634-3020 
US Army Engineering and Housing Support Center:

Commander

US Army Engineering and Housing Support Center

ATTN: CEHSC-FB-P (Mr. Stan Nicke11)

Fort Belvoir, VA 22060-5516

Telephone: 703-355-0040

Facsimile: 703-780-5935

Points of contact at Rock Island Arsenal, Illinois, and Aberdeen Proving

Ground, Maryland, where crack and seat demonstrations occurred are:

Rock Island Arsenal

ATTN: SMCRI-EHS (Mr. Chuck Swynenberg)

Rock Island Arsenal, IL 61299-5000

Telephone: 309-782-2445

Directorate of Engineering and Housing

ATTN: STEAP-FE-ER (Mr. Mark Schaller)

Aberdeen Proving Ground, MD 21005-5001

Telephone: $301-278-3588$ 


\section{PART II: PREACQUISITION}

\section{Description of Cracking and Seating}

The performance of rehabilitated PCC pavements with AC overlays is often marginal and only a temporary solution. One of the shortcomings of this rehabilitation technique is the eventual occurrence of reflective cracking which is the development of a crack pattern in the asphalt overlay similar to the crack pattern in the underlying PCC pavement. Cracks and joints of the PCC pavement eventually propagate up through the new asphalt overlay causing deterioration of the pavement. Rehabilitation techniques that provide improved performance at lower costs are very important to pavement engineers due to the increasing maintenance requirements of rigid pavements.

One method that has been used to reduce or prevent the potential for reflective cracks in asphalt overlays on PCC pavements is the cracking and seating procedure. Cracking and seating the PCC pavement has been used for over 25 years as a method to prevent reflective cracking. New improvements in cracking equipment and a better understanding of the method primarily due to experience have encouraged the use of this technique. Good pavement performance in asphalt overlays using the crack and seat method have been widespread.

Cracking and seating of PCC pavement is a process that involves cracking the PCC into predetermined sizes and then seating the cracked pieces by rolling with a heavy pneumatic-tired roller. The cracking is accomplished by any suitable method that creates hairline cracks that completely penetrates the PCC. The seating prevents the PCC pieces from further movement under traffic loading. The cracking and seating procedure is completed by applying an $\mathrm{AC}$ overlay.

\section{Application}

The cracking and seating rehabilitation technique is used to prevent and reduce reflective cracks when overlaying PCC slabs with AC. This procedure is recommended for nonreinforced jointed PCC slabs that have deteriorated to a condition where the PCC pavement cannot be economically repaired using 
standard concrete repair techniques. This technique is best suited for PCC slabs that have a thickness of 6 to 10 inches.

\section{Limitations/Disadvantages}

The crack and seat procedure should not be considered for all PCC pavement rehabilitation projects. This rehabilitation technique cannot be used to rehabilitate structurally unsound PCC pavements. PCC pavements that have weak subgrades, low strength base courses, and failed or shattered slabs have to be removed or repaired prior to using the crack and seat method. If a majority of the slabs have to be removed and replaced, then the cracking and seating procedure may not be a feasible alternative.

PCC pavements that have multiple utilities or sensitive equipment located near the pavement may not be good candidates for the crack and seat procedure because of the vibrations produced by the cracking operation. Pavements that have critical grades or drainage patterns may also be difficult to rehabilitate because a minimum asphalt overlay of 4 inches is required.

Cracking and seating of reinforced PCC pavements is not recommended because of the unknown effect of the reinforcing steel on the performance of asphalt overlay. The reinforcing steel may cause the PCC pavement to move at designated locations and not spread out the horizontal and vertical movements, thus concentrating the stress on certain locations causing reflective cracks. Cracking and seating plus overlay cannot be used where geometric constraints will not tolerate the overlay or where the cost of accommodating surface drainage, curb and gutter to the overlay is very high.

\section{FEAP Demonstration/Implementation Sites}

In FY 84, a crack and seat demonstration was conducted at Rock Island Arsenal, Illinois. An 80 - by 400 -feet PCC parking lot located adjacent to Building 350 was chosen to demonstrate this rehabilitation technique. The existing PCC pavement contained faulted and shattered slabs, spalled joints, and had deteriorated into a maintenance headache. The PCC slabs were cracked into pieces approximately 18 inches square and then seated with a 50-ton rubber-tired roller. After the cracking and seating procedures were 
completed, 4 inches of $\mathrm{AC}$ were placed. This resurfacing project was completed in 1984 .

A visual inspection was conducted in August 1990 to determine the condition of the pavement surface after 6 years of service. No reflective cracks had developed in the AC overlay. The only crack that had developed was in the longitudinal construction joint that runs above the drainage system. The pavement surface was in excellent condition and was performing extremely well.

The cracking and seating method had prevented reflective cracks in this $A C$ overlay for 6 years. No maintenance or repair has been required for this pavement. The pavement engineers at AMC Headquarters and Rock Island Arsenal DEH feel this process and project have been a success. Rock Island Arsenal has since used this technique on two other PCC pavements and had good success.

In FY 87, Maryland Boulevard at Aberdeen Proving Ground was rehabilitated with the crack and seat procedure. Maryland Boulevard is a 4-lane roadway that serves as a primary access to the installation. The existing nonreinforced PCC pavement was resurfaced using the crack and seat method. The PCC slabs were cracked into pieces approximately 2 feet square and then seated with a heavy (approximately 35 tons) pneumatic-tired roller. The cracked and seated pavement was then overlayed with 8 inches of AC. The AC overlay was completed in the spring of 1987.

A visual inspection was conducted in August 1990 to determine the general condition of the pavement surface. No transverse cracks were evident in the pavement surface. Some fine hairline cracks had developed over the longitudinal construction joint. This inspection indicated that the crack and seat method was preventing reflective cracks.

The entire 1.9 miles of Maryland Boulevard were in excellent condition. No maintenance had been conducted on this roadway since the completion of the resurfacing project. Personnel at Aberdeen Proving Ground were very satisfied with the performance of the crack and seat rehabilitation project.

\section{Life-Cycle Costs and Benefits}

Based on the demonstration projects, the simple pay back in using the cracking and seating method is approximately 3 years. The actual cost 
avoidance at Aberdeen Proving Ground was $\$ 1.2$ million, which represents a savings of 36 percent of the construction costs. The cracking and seating method reduced costs by $\$ 10$ per square yard at Rock Island Arsenal when compared to the next best alternative.

The costs for cracking and seating are minimum and vary from $\$ 0.25$ to $\$ 1.00$ per square yard. Actual cost savings of 30 to 50 percent can be realized when cracking and seating and overlaying with $A C$ is used instead of removing deteriorated PCC slabs. Cracking and seating of PCC pavements can result in construction savings of approximately 30 to 50 percent and annual maintenance savings of 15 percent.

\section{Advantages/Benefits}

Besides the cost savings, the benefits of the cracking and seating rehabilitation technique are numerous. Reflective cracks are reduced, retarded, and even prevented which extends the service life of the AC overlay. The AC overlay also improves the rideability and surface smoothness and restores the skid resistance. During pavement rehabilitation, the disruption of traffic is decreased when compared to standard PCC repair techniques. 


\section{PART III: ACQUISITION/PROCUREMENT}

\section{Potential Funding Sources}

Typically, installations fund the implementation of Pavements and Railroads technologies from their annual budgets. However, the annual budget is always underfunded and normally the Pavements and Railroads projects do not compete well with other high visibility/high interest type projects. As a result, it is in one's best interest to seek all of the funds possible from other sources when the project merits the action. Listed below are some sources commonly pursued to fund projects.

a. Productivity program. See AR 5-4, Department of the Army Productivity Improvement Program for guidance to determine if the project qualifies for this type of funding.

b. Facilities Engineering Applications Program (FEAP). In the past, a number of Pavement and Railroad maintenance projects located at various installations were funded with FEAP demonstration funds. At that time, emphasis was placed on demonstrating new technologies to the Directorate of Engineering and Housing (DEH) community. Now that these technologies have been demonstrated, the installations will be responsible for funding their projects through other sources. However, emphasis concerning the direction of FEAP may change in the future; therefore, one should not rule out FEAP as a source of funding.

c. Special programs. Examples of these are as follows:

(1) FORSCOM mobilization plan which may include rehabilitation or enlargement of parking areas and the reinforcement of bridges.

(2) Safety program which may include the repair of unsafe/ deteriorated railroads at crossings and in ammunition storage areas.

(3) Security upgrade which may include the repair or enlargement of fencing.

d. Reimbursable customer. Examples of this source are roads to special function areas such as family housing or schools and airfield pavements required to support logistical operations.

e. Special requests from MACOMS. 
f. Year end funds. This type funding should be coordinated with the MACOMS to ensure that the funds will not be lost after a contract is advertised.

g. Operations and Maintenance Army. These are the normal funds used for funding pavement and railroad projects.

\section{Technology Components and Sources}

Components of this technology which must be procured to rehabilitate a PCC pavement with the cracking and seating method are pavement preparation, cracking and seating the existing PCC pavement, and overlaying with AC. A paving contractor is required to perform conventional pavement preparation and AC placement. An additional contractor (or a subcontractor) may also be required to break or crack the PCC pavement if the paving contractor is not equipped with pavement breaking equipment.

All of the items used in the cracking and seating rehabilitation method are conventional paving equipment and procedures that are used by the construction industry. No special materials or procedures are required.

\section{Procurement Documents}

A standard Corps of Engineers Guide Specification (CEGS) for the cracking and seating procedure is not available. An Engineering Technical Letter (ETL 1110-1-0006), "Cracking and Seating of Nonreinforced Portland Cement Concrete for Asphalt Concrete Overlay," was published in 1990 and provides guidance on the use of this rehabilitation technique. The ETL also contains an interim construction specification that can be used for cracking and seating rehabilitation projects. A standard CEGS should be used for the AC overlay. The typical specifications for AC are CEGS 02551 "Bituminous Paving for Roads, Streets and Open Storage Areas" and CEGS 02556, "Bituminous Intermediate and Wearing Courses (Heavy-Duty Pavements").

The construction specification for a crack and seat project will be site specific and should meet the needs of the installation. The contract specifications will need to be developed by in-house personnel. 


\section{Procurement Scheduling}

Normal construction contract schedules should be established that would allow verification of the absence of reinforcing steel in the PCC slab, adequate design and plan preparation time; design, review and approval; contract preparation; advertising and award; and construction time. A typical pavement project is designed 1 to 2 years before it is constructed; however, relatively small projects that require limited plans and specifications can be prepared and ready to go within a few months. 


\section{PART IV: POST ACQUISITION}

\section{Initial Implementation}

\section{Equipment}

Standard paving equipment is used to construct a crack and seat rehabilitation project. Conventional asphalt paving construction equipment is used to prepare the pavement surface and to place the AC overlay. Conventional PCC pavement breakers including a modified pile driver, impact hammer, guillotine hammer, or whiphammer should be used to produce the desired cracking pattern.

\section{Material}

The AC material recommended for use with a crack and seat project is a standard dense-graded asphalt mixture. The AC should meet requirements of CEGS 2551, CEGS 2556, or a high-quality state highway specification.

The thickness of the asphalt overlay depends on the condition of the existing pavement structure and the amount and type of traffic. The overlay thickness should always ensure the new pavement structure will be structurally adequate. The minimum recommended overlay thickness for a crack and seat project is 4 inches.

\section{Personnel}

Regular paving construction personnel are used in a crack and seat rehabilitation project. In the demonstration projects, a paving contractor performed all of the construction except for the cracking at the PCC pavement. The cracking portion of these projects was subcontracted to a paving contractor that specialized in breaking PCC pavements. Installation personnel provided project design, inspection, and contract administration.

\section{Procedure}

Given the need to rehabilitate a PCC pavement, the procedure has two major steps:

a. Establish a cost-effective solution from one of the three options listed:

(1) Repair existing PCC pavement using concrete pavement restoration techniques.

(2) Remove and repair existing PCC slabs. 
(3) Crack and seat PCC slabs and overlay with AC.

b. If the crack and seat method is cost effective, the design of the pavement rehabilitation must be prepared. Factors to be considered include determining existing PCC pavement parameters; thickness, joint spacing, condition of joints, drainage, subgrade strength and the absence of reinforcing steel in the PCC slabs. Specifics concerning the cracking pattern will have to be specified according to crack pattern and size and type of cracking equipment.

The recommended construction procedures will be site specific and vary with the conditions of the existing PCC pavement. The following are general construction procedures that are recommended for cracking and seating of PCC pavements.

a. Shattered and failed slabs should be removed and repaired using highquality base course material of full-depth hot-mix AC.

b. Old joint and crack sealant material should be removed to a minimal depth of 1 inch below the pavement surface.

c. Proper drainage should be established to prevent weakening of the pavement structure.

d. The existing PCC slabs should be mechanically broken into pieces approximately 24 inches square. These cracks should be hairline and penetrate through the full depth of the PCC pavement. The minimum size of any piece should be limited to 12 inches, and the maximum size should be limited to 36 inches.

e. The cracked PCC should then be seated or rolled with a heavypneumatic-tired roller. The recommended roller should weigh between 30 to 50 tons and have tire pressures of 90 to $150 \mathrm{psi}$. The seating of a cracked PCC pavement on a road normally requires three to five coverages.

f. The cracked and seated PCC pavement should be cleaned and prepared. All loose debris and material should be swept off and a bituminous tack coat applied.

g. A conventional AC overlay is placed to complete the rehabilitation project.

\section{Operation and Maintenance}

Operation and maintenance of a cracked and seated PCC pavement are no different than that of any conventional AC overlay. Past experience with this rehabilitation technique has indicated that the pavement service life is 
increased and that maintenance is delayed and reduced. The performance of a crack and seat project will depend upon a combination of factors including pavement thickness, local climatic conditions, and the amount of traffic.

\section{Service and Support Requirements}

No special services or support are required to implement or maintain this technology.

\section{Performance Monitoring}

Installation personnel can monitor and measure the performance of the crack and seat rehabilitation technique by making periodic inspections of the surface for signs of distress (cracking, rutting, etc.). Unusual traffic or climatic conditions could adversely affect performance and should be noted. The asphalt overlay should be considered to be performing satisfactorily, provided that reflective cracks have been eliminated or reduced. Poor performance will exhibit moderate to severe reflective cracking in the new asphalt overlay. 
APPENDIX A: AD FLIER 


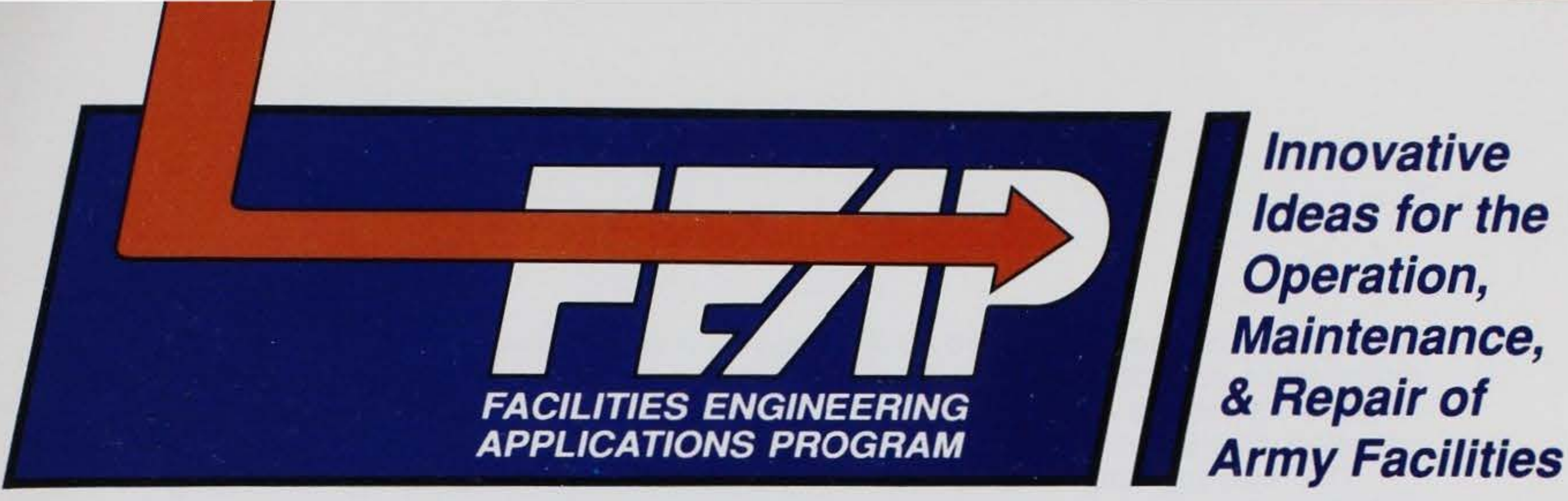

\section{Cracking and Seating Pavement Rehabilitation}
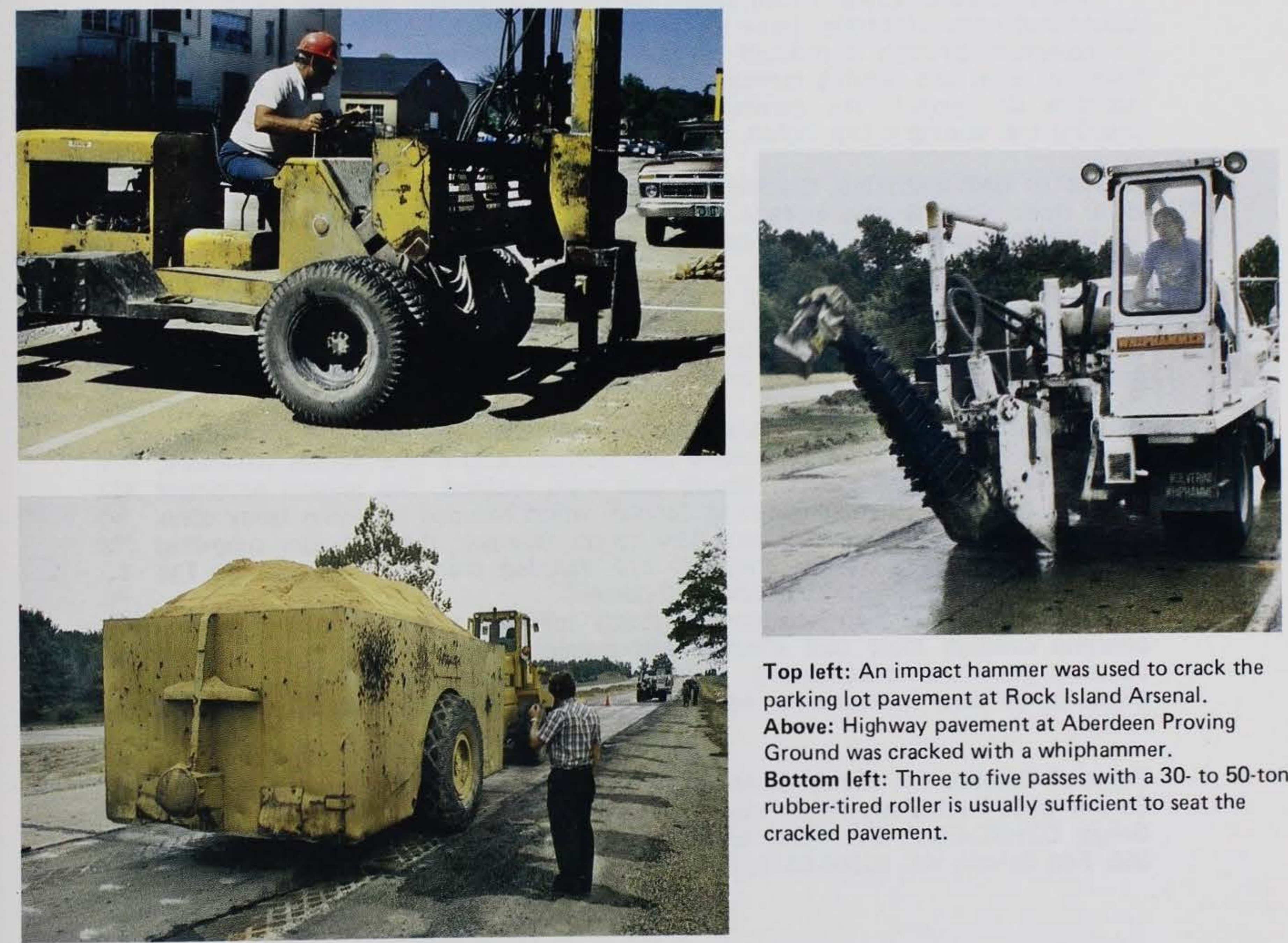

Top left: An impact hammer was used to crack the parking lot pavement at Rock Island Arsenal. Above: Highway pavement at Aberdeen Proving Ground was cracked with a whiphammer.

Bottom left: Three to five passes with a 30- to 50-ton rubber-tired roller is usually sufficient to seat the cracked pavement.

PROBLEM: When rehabilitating portland cement concrete pavements with asphalt concrete overlays, reflective cracks usually develop, causing rapid deterioration of the new pavement overlay.

TECHNOLOGY: Cracking and seating eliminates the concrete slab movement that causes reflective cracking in asphalt concrete pavement overlays.

DEMO SITES: Rock Island Arsenal, IL - FY 84

Aberdeen Proving Ground, MD - FY 87

BENEFITS: $\$ 1.2$ million savings in construction costs at Aberdeen; reduced costs by $\$ 10$ per square yard at Rock Island. 
Description of Technology. To save money in portland cement concrete pavement rehabilitation projects, asphalt concrete pavement overlays are often used. However, reflective cracks will eventually appear in the asphalt concrete overlay, causing rapid pavement deterioration and increased maintenance costs.

The cracking and seating method retards reflective cracking by preventing rocking or movement of the existing pavement. This is achieved by carefully cracking the existing concrete slabs into pieces, ranging from 18 to 36 inches, depending on the pavement characteristics. A proper crack pattern will produce hairline cracks and small slab segments with the required aggregate particle interlock.

The cracked concrete is then seated on the subgrade with a heavy (30-50 ton) rubber-tired roller. Generally, three to five passes by the roller are adequate. While the pavement strength is reduced by cracking and seating, the cracked layer still functions as a load carrying medium. An asphalt concrete overlay is then placed to complete the project. The minimum recommended thickness of the overlay for cracking and seating is four inches.

Details of Demonstration. Cracking and seating was used to rehabilitate a parking lot at Rock Island Arsenal in 1984. An impact hammer broke the existing slabs into 18- to 24-inch pieces. A 50-ton roller made two passes before four inches of asphalt concrete were placed.

At Aberdeen Proving Ground, a four-lane highway with 5,800 vehicles-per-day traffic was cracked and seated. A whiphammer cracked the slabs into 24-square-inch segments. Three passes of a 50-ton roller seated the cracked slabs. Eight inches of asphalt concrete was then placed over the slabs.

Benefits of Technology. At Rock Island, the unit cost of cracking and seating was approximately half the price of removal and reconstructing a new flexible pavement. Actual savings of over $\$ 10$ per square yard were realized. The original pavement rehabilitation bid at Aberdeen Proving Ground, which included removing faulty slabs and overlaying asphalt concrete, was $\$ 3.4$ million. However, the contractor submitted a Value Engineering Change Proposal that included cracking and seating. The savings was over $\$ 1.2$ million, or about 30 percent.

Cracking and seating successfully retards reflective cracking, making asphalt concrete overlays more cost effective and maintenance free for portland cement concrete pavement rehabilitations. Cracking and seating also allows construction efforts to be done in segments, easing traffic control while decreasing construction time.

Point of Contact. Mr. Randy C. Ahlrich, U.S. Army Engineer Waterways Experiment Station, 3909 Halls Ferry Road, Vicksburg, MS 39180-6199, 601-634-3367. Mr. Ken Gregg, CEHSC-FB-P, U.S. Army Engineering and Housing Support Center, Building 358, Fort Belvoir, VA 22060-5516, COMM 703-355-3931. 
APPENDIX B: TECHNICAL REPORTS 
Ahlrich, R. C. 1989. "Performance and Structural Evaluation of Cracked and Seated Concrete," Transportation Research Record 1215, Washington, DC.

Ahlrich, R. C. and Godwin, L. N. 1991. "Cracking and Seating of PCC Pavements," Video Report GL-91-1, US Army Engineer Waterways Experiment Station, 'Vicksburg, MS.

Godwin, L. N. 1985. "Cracking and Seating of Portland Cement Concrete Pavements," Facilities Applications Test Program, Video Report GL-85-3, US Army Engineer Waterways Experiment Station, Vicksburg, MS .

. 1986. "Cracking and Seating of Portland Cement Concrete Pavement Prior to Asphalt Concrete Overlay; Facilities Technology Application, Test, FY84," Miscellaneous Paper GL-86-3, US Army Engineer Waterways Experiment Station, Vicksburg, MS. 
APPENDIX C: ENGINEERING TECHNICAL LETTER 
Engineer Technical

Letter 1110-1-0006

19 January 1990

\section{Engineering and Des1gn \\ CRACKING AND SEATING OF NONREINFORCED PORTLAND CEMENT CONCRETE FOR ASPHALT CONCRETE OVERLAY}

1. Purpose. This letter provides guidance on the use of cracking and seating of nonreinforced portland cement concrete (PCC) pavements prior to overlaying with asphalt concrete.

2. Application. This letter applies to all OCE elements and all field operating agencies having military construction and/or civil works design responsibility.

3. Discussion.

a. Cracking and seating is recommended when PCC slabs have deterforated to a condition where they cannot be economically repaired. This deterioration includes distresses ranging from spalled or separated joints which can no longer be properly sealed to the complete fallure of the slab. Cracking or breaking the slabs into smaller sections is intended to reduce the amount of movement or rocking of the slabs to levels where the asphalt pavement placed above the slab does not crack. Cracking and seating of PCC pavements will reduce, but not prevent, the reflective cracking of asphalt concrete overlays.

b. This ETL provides a specification for cracking and seating of nonreinforced portland cement concrete. Cracking and seating of reinforced portland cement concrete can be accomplished by simflar procedures. The effect of the reinforcing steel on the performance of asphalt overlays is currently not well defined; however, initial results indicate that this process can be used for reinforced portland cement concrete.

4. Action To Be Taken. The enclosed guide specification should be considered for use whenever specifying an asphalt concrete overlay of nonreinforced portland cement concrete.

5. Implementation. This letter will have routine application for military construction as defined in Paragraph 6c, ER 1110-345-100, and will apply to all civil works projects, except where local requirements govern.

FOR THE COMMANDER:

1 Encl

HERBERT H. KENNON

Chief, Englneering Division

Directorate of Military Programs 
ETL $1101-1-0006$

\section{CRACKING AND SEATING OF NONREINFORCED PORTLAND CEMENT CONCRETE FOR ASPHALT CONCRETE OVERLAY}

\section{PART 1 - GENERAL}

1. SCOPE. This specification covers the cracking and seating of nonreinforced portland cement concrete pavement in preparation for an asphalt concrete overlay.

\section{EQUIPMENT:}

2.1 General: The equipment used for cracking portland cement concrete pavement shall be capable of producing the specifled cracking pattern without causing excessive spalling or punch-throughs.

2.2 Cracking Equipment: The cracking equipment used shall be modified pile-driver or falling-weight hammers, or hydraulic or pneumatic impact hammers. Chisel-shaped impact heads, gravity balls, or other equipment that produces rubble will not be allowed.

(1) 
ETL 1101-1-0006

19 Jan 90

\section{PART 2 - PRODUCTS}

5. CRACKED PAVEMENT: The existing portland cement concrete pavement shall be cracked into pieces ..... inches nominal size, with a maximum size of ..... inches. A cracking pattern which results in a continuous longitudinal crack will not be allowed. Cracks shall extend the full depth of the portland cement concrete pavement. Spalling of the PCC pavement surface will not be allowed.

\section{PART 3 - EXECUTION}

6. EXISTING PAVEMENT CONDITIONING: The existing joint and crack sealer material shall be removed prior to the cracking of the pavement. The sealer material shall be removed to a minimal depth of 1 inch below the pavement surface. Where the joint or crack widths are greater than $3 / 4$ inch they shall be filled flush to the pavement surface with a sand mix. Prior to cracking the pavement, the surface shall be cleaned of all loose material by sweeping or with forced air.

7. TESTING OF PROCEDURE: Prior to starting the job, the Contractor shall demonstrate the cracking procedure in a designated test area. The test area shall be large enough for the Contractor to demonstrate a suitable cracking pattern, meeting the requirements given in this specification. Various patterns shall be tried until a sultable cracking pattern is found. A minimum of three cores shall be taken through the cracks of the final selected pattern to assure full depth cracks. The Contractor shall have a suitable method avallable to dampen the pavement to enhance a visual determination of the cracking pattern. Following the cracking, the pavement section shall be rolled to seat the pavement. A minimum of ..... coverages shall be made with the roller. One coverage is the application of a load bearing tire over the entire area being seated.

8. CONSTRUCTION:

\subsection{Drainage:}

8.2 Cracking: The existing PCC slabs shall be cracked into sizes as specified in paragraph: CRACKED PAVEMENT. The Contractor shall wet a portion of the newly cracked pavement at least once a day with the minimum amount of water that allows for visual verification of the proper cracking pattern. Adjustments to the cracking pattern shall be made, when approved, to maintain the specified cracking pattern. 
ETL 1101-1-0006

19 Jan 90

(M)

8.3 Seating: A Government quality assurance representative shall be present during the rolling and along with the Contractor's quality control representative, they shall mark areas of pavement distress revealed by the rolling. If displacements greater than $1 / 2$ inch occur during rolling, the number of coverages required may be reduced in that area. Areas where the roller has caused punch-throughs, shattered slabs, or rocking slabs shall be repalred. These areas shall be repaired by filling the holes with asphalt mix conforming to SECTION: [BITUMINOUS PAVING FOR ROADS, STREETS, AND OPEN STORAGE AREAS] [BITUMINOUS INTERMEDIATE AND WEARING COURSES HEAVY DUTY PAVEMENTS]. 
ETL 1101-1-0006

19 Jan 90

GENERAL NOTES

1. This guide specification is to be used in the preparation of project specifications in accordance with ER 1110-345-720 for military construction or ER 1110-2-1200 for civil works. It will not be made a part of a contract merely by reference; pertinent portions will be copied verbatim into the contract documents.

2. The capital letters in the right-hand margins indicate that there is a technical note pertaining to that portion of the guide specification. It is intended that the letters in the margins be deleted before typing the project specifications.

3. Where numbers, symbols, words, phrases, clauses, or sentences in this specification are enclosed in brackets [ ], a choice or modification must be made; delete inapplicable portions carefully. Where blank spaces occur in sentences, insert the appropriate data. Where entire paragraphs are not applicable, they should be deleted completely. 
ETL 1101-1-0006

19 Jan 90

\section{TECHNICAL NOTES}

A. Paragraph 1: The effect of cracking and seating on a reinforced PCC pavement is not fully known; however, several states have cracked and seated reinforced $P C C$ pavement with reported satisfactory results.

B. Paragraph 2.2: This paragraph may be adjusted to require a particular type of cracking device, where local or previous experfence warrants. Equipment manufacturer's data may be used to assure that suitable production rates are possible with proposed equipment.

C. Paragraph 2.3: The heavy pneumatic-tired roller (proof roller) normally used is a single axle, towed vehicle which can be ballasted to the required load. This roller has tire pressures of $150 \mathrm{ps} 1$ and a load of 25,000 pounds on each wheel. These requirements can be reduced for low volume, low tire pressure applications. The minimums used in any roller operation should be 90 ps 1 for tire pressure and loads of 6,500 pounds per wheel.

D. Paragraph 3: A pavement that has been cracked and seated should be overlayed as soon as possible to prevent water intrusion through the pavement. Some trafficking is possible during construction; however, the cracking and seating will have weakened the pavement and this can cause problems if there is a weak subgrade beneath the pavement. Depending on the location, this problem can be seasonable and most severe in the spring when subgrades are usually their wettest and weakest.

E. Paragraph 4: Delete this paragraph when lump sum bidding is used.

F. Paragraph 5: It is recommended that the pavement be broken into 18 to 24 inch squares. The maximum size of any piece should be limited to 36 inches to prevent bridging over weak areas and rocking slabs. The minimum size of any piece should be limited to 12 inches to prevent spalling and excessive loss of structural strength. The thickness of the pavement being cracked will effect the size of pleces desired. As a rule the size to thickness ratio should remain between 2 and 4 to 1 .

G. Paragraph 6: 01d joint and crack sealer material must be removed to prevent slippage cracks and to prevent the sealer material from bleeding through the surface of the new asphalt concrete overlay. The sealer material is best removed by routing. Sealer material on the surface of the pavement can be removed by heating and scraping or any other suitable method, such as high pressure water systems and various grinding techniques. Manufacturer's recommendations should be followed when specifying these types of equipment.

H. Paragraph 7: A representative section of the pavement to be overlayed should be selected for the test section. 
ETL 1101-1-0006

19 Jan 90

I. Paragraph 7: The cracks obtained in the PCC pavement will normally be hairline cracks. These cracks are difficult to see without wetting the pavement.

J. Paragraph 7: The minimum number of coverages used in low tire pressure areas (roads) should be at least 2, with 3 to 5 coverages normally used. High tire pressure areas (airfields) require more coverages than roads, with 10 to 30 coverages used, depending on type of aircraft and the thickness of asphalt concrete overlay. The largest proof roller as described in technical note $C$ is required for airfleld use. The roller is used to seat the slabs and the number of coverages required will depend on the strength and condition of the subgrade. The softer or wetter the subgrade, the fewer the number of coverages that can be placed on the pavement.

K. Paragraph 8.1: This paragraph should include all requirements necessary to provide satisfactory drainage. Applicable sections of one of the following specifications should be used: STORM-DRAINAGE SYSTEM or SUBDRAINAGE SYSTEM. In addition, a section on GRADING can be included to help provide for proper drainage. Proper drainage is critical for cracked and seated PCC pavement as the pavement structure has been weakened, and if not properly drained it will weaken further.

L. Paragraph 8.2: When the PCC pavement to be cracked and seated passes over culverts or utility conduits, include the following sentence as part of the specification. "Cracking will not be allowed over culverts or utility conduits as these may be damaged."

M. Paragraph 8.3: Underrolling will result in unexposed weak areas, while overrolling will damage the subgrade and lower pavement strength. The number of coverages set in paragraph 7 will have to be monitored and adjusted up or down depending on the condition of the pavement.

END 